\title{
Elektrokoagülasyon Yöntemi ile Sulardan Boyarmadde Gideriminde Molekül Büyüklüğü ve pH etkisi
}

\author{
${ }^{1}$ Leyla GAZİGIL, ${ }^{2 *}$ Orhan Taner CAN \\ ${ }^{1}$ Bitlis Eren Üniversitesi, Çevre Mühendisliği Bölümü, Bitlis \\ ${ }^{2}$ Bursa Teknik Üniversitesi, Çevre Mühendisliği Bölümü, Bursa
}

\section{$\ddot{O ̈ z}$}

\begin{abstract}
Elektrokoagülasyon koloitlerin atıksulardan giderilmesinde kullanılan önemli arıtma yöntemlerinden biridir. Boyarmaddeler atıksulardaki önemli koloit kaynaklarının başında gelirler. Tekstil endüstrisinde oldukça fazla kullanılan boyarmaddeler, endüstrinin kullandığı su miktarının fazlalığı da göz önüne alındığında alıcı su ortamları için önemli kolloidal kirleticiler haline gelirler. Bu çalışmada farklı molekül ağırlığındaki iki ayrı tekstil boyar maddesi kullanılarak kirletici koloitlerin molekül ağırlığının elektrokoagülasyonda giderme verimine ne şekilde etki ettiği incelendi. Bu amaçla alüminyum elektrotların kullanıldığı reaktöründe renk giderme çalışmaları yapıldı. Çalışma farklı pH değerlerinde yapılarak farklı flok yapılarının (büyüklüklerinin) etkileri de incelendi. $\mathrm{pH}$ artışından daha büyük molekül ağırlığına sahip olan boyarmadde daha çok etkilendiği tespit edildi. Boyarmadde gidermede daha büyük molekül ağırlığına sahip olan Reactive Black 39 (1021.16 g/mol) pH değişiminden \% 100 'den 74.83 'e düşüşle, yaklaşık \% 25 oranında etkilenirken, daha küçük molekül ağırlığına sahip olan Remazol Red 3B (674.10 g/mol) \% 96.54 'den 83.01 'e düşüşle yaklaşık \% 13 oranında etkilenmektedir.
\end{abstract}

Anahtar Kelimeler: Elektrokoagülasyon, Boyarmadde, Molekül Büyüklüğü, Renk Giderimi.

\section{Molecular Weight and pH Effect on Removal of Dyestuffs from Water by Electrocoagulation Method}

\begin{abstract}
Electrocoagulation is one of the important treatment methods used to remove colloids from wastewater. Dyestuffs are the leading source of colloids in wastewaters. Dyestuffs, which are used extensively in the textile industry, become important colloidal pollutants for the receiving water environments, given the increased amount of water used by the industry. In this study, the effect of molecular weight of pollutant colloids on the removal efficiency of electrocoagulation was investigated by using two different textile dye materials with different molecular weights. For this purpose, color removal studies were carried out in the reactor where aluminium electrodes were used. The study was carried out at different $\mathrm{pH}$ values and the effects of different flock structures (size) were also studied. It was found that the $\mathrm{pH}$ a was more affected than the dye having a larger molecular weight. The Reactive Black 39 (1021.16 g / mol), which has a higher molecular weight in the dyestuffs, has Remazol Red 3B (674.10 g / mol), which has a smaller molecular weight, while being affected by a change of $\mathrm{pH}$ from $75 \%$ to $74.83 \%$ It is affected by $13 \%$, down from 96.54 to 83.01 .
\end{abstract}

Keywords: Electrocoagulation, Dyestuffs, Molecular Weight, Color Removal

\section{Giriş}

Kirleticilerin su ve atıksulardan giderimi için pek çok yöntem kullanılmaktadır. Bu kirleticilerin önemli bir kısmını kolloidaller oluşturmaktadır. Kolloidallerin giderilmesi temelde bir fiziksel veya fiziko-kimyasal ayırma gerektirir. Kirleticinin (Kolloidalin) türü, boyutu, suya tutunma şekli gibi özellikleri seçilecek arıtma (ayırma) yönteminin belirlenmesinde en önemli faktördür.
Tekstil endüstrisinin yüksek su tüketimi dolayısıyla atıksu üretimi fazladır. Bu atıksulardaki kirleticilerin önemli bir kısmını boyamada kullanılan boyar maddeler oluşturmaktadır. [1-2] Boyar madde atıksuya renk vermektedir. Renkli tekstil atıksuları alıcı su ortamlarında birikerek suyun hem estetik görünümü bozar hem de 1şı geçirgenliğini azaltır. Işık geçirgenliğinin azalması ve çözünmüş oksijen miktarının düşmesi canlıların yok olmasına sebep olur. Ayrıca boyamada kullanılan boyarmaddelerin bazıları toksik bileşenler içerirler [3]. 
Boyarmaddelerin atıksulardan gieriminde pek çok yöntem kullanılmıştır.

Atıksulardan boyarmadde (renk) gideriminde en çok kullanılan 4 yöntem şu şekilde sıralanmaktadır.

Fiziksel veya fiziko-kimyasal yöntemler; yani çöktürme, koagülasyon veya flokülasyon, iyon değiştirme, adsorpsiyon ve membran prosesler. Bunlar fiziksel olarak renk giderme yöntemleridir ve oluşan çamurun (konsantrenin) katı atıkların atılmasını gerektirir.

Kimyasal yöntemler; yani ozonlama, kimyasal oksidasyon / indirgeme, vb. Bu teknolojiler, atıktan rengi daha basit alt bileşenlere ayırarak rengi giderir ve renkten sorumlu kromo gözenekleri yok eder.

Biyolojik yöntemler; örneğin aerobik ve anaerobik arıtma, burada renksizleştirme işlemi, aktif çamurdaki boyaların adsorbe edilmesiyle veya boya moleküllerinin biyolojik olarak parçalanmasıyla gerçekleşir. Ancak biyolojik yöntemler çok fazla zaman alır ve bazen boyarmaddeleri tam olarak parçalayamazlar. [4] Üstelik bazı boyarmaddeler bazı organizmalar için toksik etki gösterirler. [5] Elektrokimyasal yöntemler; yani elektrooksidasyon, elektroflotasyon, elektrodiyaliz / iyon oksidasyonu. Boya ve diğer kirleticilerinin oksidasyonunu çamurun fizik-kimyasal çöktürmesi ile elektrolitik işlemle gerçekleştirilir. [6]

Elektrokimyasal yöntemlerden biri olan elektrokoagülasyon boyarmadde gideriminde önemli avantajlara sahip etkili bir yöntemdir. [7]. Bu yöntem ile renk gideriminde yüksek verimler elde edilmiştir. [8][9][10] $\mathrm{Bu}$ yöntemin en büyük dezavantajını üretilen çamur ve bu çamurun bertaraf edilmesi oluşturmaktadır. [11]

Elektrokoagülasyon yöntemi ile Acid Black 52 ve Acid Yellow 220 boyarmaddeleri kullanılarak gerçekleştirilen renk giderimi çalışmasında, akım yoğunluğunun $40 \mathrm{~A} / \mathrm{m}^{21}$ ye kadar yükselmesinin boya giderme verimliliğini $\operatorname{arttırdığı~ve~}$ elektrokoagülasyon işlemi için optimum pH'ın 5 olduğu bulunmuştur. [12]

Ardhan ve ark. yaptı̆̆ı çalışmada; reactive blue 21 boyası elektrokoagülasyon yöntemi ile giderilmeye çalışılmıştır. Çalışma sonuçlarından 30 A / m2 akın yoğunluğunda, 7 dakikalık deney süresi sonunda \% 95 oranında renk giderimi elde edilmiştir. [13]
Nandi ve ark. demir elektroların kullanıldığı kesikli ve tam karıştırmalı elektrokoagülasyon reaktöründe Brilliant Green boyasını gidermeye çalışmışlardır. Çalışma sonucunda $100 \mathrm{mg} / \mathrm{L}$ boya konsantrasyonuna ve $4.0 \mathrm{pH}$ giriş değerine sahip çözeltiden, $41.7 \mathrm{~A} / \mathrm{m}^{2}$ akım yoğunluğu ve 30 dakikalık deney süresi sonunda \%99.59 oranında renk giderimi elde edilmiştir. [14]

Mbacke ve ark. alüminyum elektroların kullanıldığ kesikli ve tam karıştırmalı elektrokoagülasyon reaktöründe Crystal Violet boyasını gidermeye çalışmışlardır. Çalışma sonucunda 15 dakikalık deney süresinde $\% 70$ ve 60 dakşkanın sonunda $\% 100$ oranında renk giderimi elde edilmiştir. [15]

Zodi ve ark. alüminyum elektroların kullanıldığ sürekli akış elektrokoagülasyon-flotasyon reaktöründe Direct Red 81 boyasını gidermeye çalışmışlardır. $10 \mathrm{l} / \mathrm{h}$ akış hızı için $100 \mathrm{~A} / \mathrm{m}^{2}$ akım yoğunluğunda \% $71.5200 \mathrm{~A} / \mathrm{m}^{2}$ akım yoğunluğunda $\%$ 90.2, $28 \mathrm{l} / \mathrm{h}$ akış hızı için $100 \mathrm{~A} / \mathrm{m}^{2}$ akım yoğunluğunda $\% \quad 61.5, \quad 200 \quad \mathrm{~A} / \mathrm{m}^{2} \quad \mathrm{ak} 1 \mathrm{~m}$ yoğunluğunda $\% 78.8,16 \mathrm{l} / \mathrm{h}$ akış hızı için $100 \mathrm{~A} / \mathrm{m}^{2}$ akım yoğunluğunda $\% \quad 62.8 \quad 200 \quad \mathrm{~A} / \mathrm{m}^{2}$ akım yoğunluğunda \% 85.4 boya giderme verimi elde edilmiştir. [16]. Amani-Ghadim ve ark. Alüminyum ve demir elektrolar kullanarak C.I. Reactive Red 43 azo boyasını gidermeye çalışmışlardır. Optimum deney şartlarında her iki elektrot içinde \%99 un üzerinde giderme verimleri elde edilmiştir. [17]

Bu çalışmada farklı molekül ağırlığındaki iki ayrı tekstil boyar maddesi kullanılarak kirletici kolloidlerin molekül ağırlığının elektrokoagülasyonda giderme verimine ne şekilde etki ettiği incelendi. $\mathrm{Bu}$ amaçla alüminyum elektrotların kullanıldığı reaktöründe renk giderme çalışmaları yapıldı. Çalışma farklı $\mathrm{pH}$ değerlerinde yapılarak farklı flok yapılarının (büyüklüklerinin) etkileri de incelendi.

\section{Materyal ve Metot}

\subsection{Materyal}

$\mathrm{Bu}$ çalışmada DyStar Türkiye firmasından temin edilen kumaş boyamada sıkça kullanılan Reactive Black 39 ve Remazol Red 3B boyarmaddeleri kullanıld1. Tablo 1'de boyarmaddelerin yapısal formülü, fiziksel ve kimyasal özellikleri gösterilmektedir. Çalışmada kullanılan diğer tüm kimyasallar Merck marka analitik saflıkta kimyasallardır 
Tablo 1. Boyarmaddelerin yapısal formülü, fiziksel ve kimyasal özellikleri

\begin{tabular}{|c|c|c|}
\hline Parametre & Reactive Black 39 & Remazol Red 3B \\
\hline & $\mathrm{SO}^{\mathrm{H}} \mathrm{H}$ & $\mathrm{NaO}_{3} \mathrm{SOC}_{2} \mathrm{H}_{4} \mathrm{SO}_{2}$ \\
\hline Eşanlanmliları & Apollocion Navy Blue P-N3G Cibacron Black ZP-2PD & Reactive Red 23 \\
\hline Colour Index No & 20507 & 16202 \\
\hline CAS numarası & $68259-02-9$ & $85585-89-3$ \\
\hline Moleküler ağırlı̆̆ı (g/mol) & 1021.16 & 674.10 \\
\hline$\lambda_{\max } \mathrm{nm}$ & 567 & 521 \\
\hline Fiziksel hali & Kristal toz (siyah) & Kristal toz (kırmıı) \\
\hline
\end{tabular}

\subsection{Deney Düzeneği}

Şekil 1 'de deneyde kullanılan reaktör ve elektrot yerleşimi (paralel bağlı bipolar reaktör) görülmektedir. Deney sisteminde reaktör olarak $1000 \mathrm{ml}$ hacme sahip payrex beher kullanıldı. Her deney için reaktöre $500 \mathrm{ml}$ boya çözeltisi yerleştirildi. Çözeltide elektrotlar arası iletkenliği sağlaması amacıyla elektrolit olarak $500 \mathrm{mg}$ (1000 $\mathrm{mg} / \mathrm{L}) \mathrm{NaCl}$ eklendi. Reaktörde elektrot bağlantı şekli paralel bağlı bipolar olarak düzenlendi. Reaktörde $60 * 200 \mathrm{~mm}$ boyutlarında 1 monopolar anot, 1 monopolar katot ve 2 bipolar elektrot olmak üzere $15 \mathrm{~mm}$ aralıklarla yerleştirilmiş toplam 4 adet alüminyum elektrot kullanıldı. Alüminyum elektrotların saflığı \%99,8 dir. Dıştaki anot ve katot elektrotların $67 \mathrm{~mm}$ lik kısmı çaözeltiye batık iken

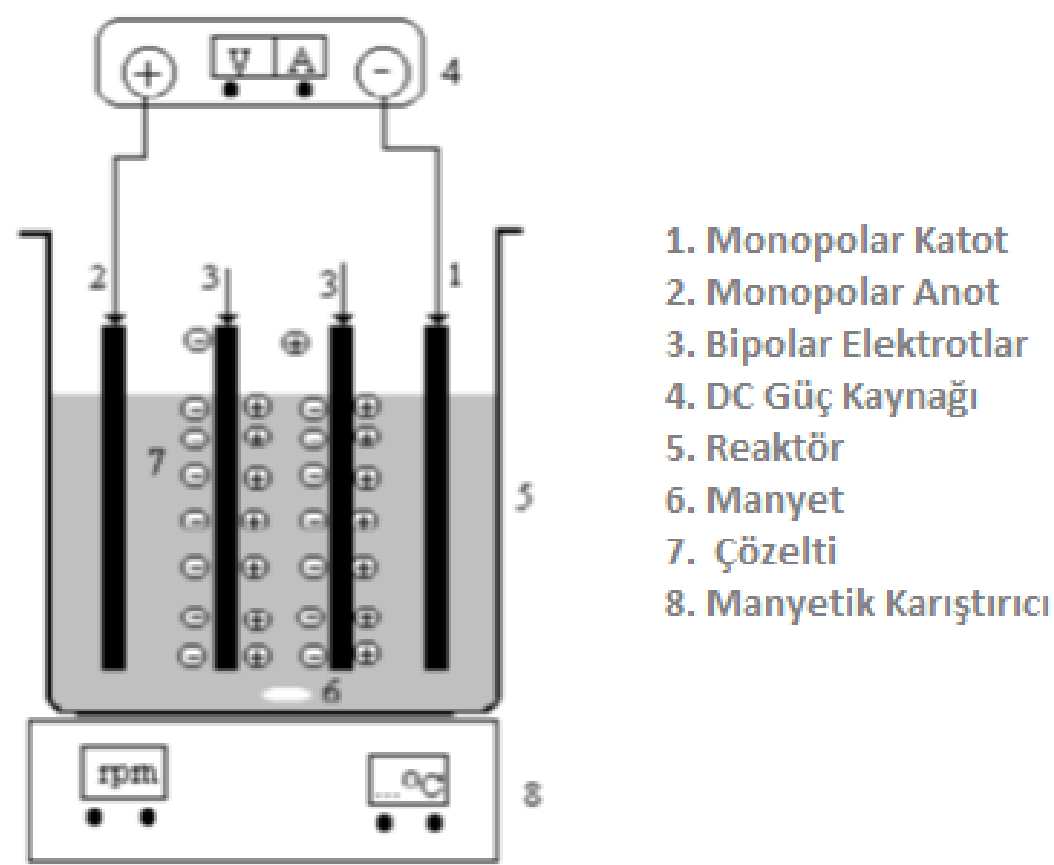

ortadaki 2 bipolar elektrodun $50 \mathrm{~mm}$ lik kısmı çözeltiye batık durumda çalıştırıldı. Bu durumda en dışta çalıştırılan elektrotların aktif yüzey alanı $60 * 67$ $\mathrm{mm}$ olup toplam $40 \mathrm{~cm}^{2}$ iken ortadaki her bir elektrodun tek taraflı aktif yüzey alanı $60 * 50 \mathrm{~mm}$ olup $30 \mathrm{~cm}^{2}$ dir. Toplam 3 aktif anot ve 3 aktif katot yüzey olup toplam aktif anot yüzey alanı $100 \mathrm{~cm}^{2}$ dir. Şekil 2 'de deney düzeneği görülmektedir. Sistemde güç kaynağı olarak Agilent marka programlanabilir (Agilent U8032A 0-60V / 0-3A Agilent U8002A 0-30V / 0-5A) dijital (D.C.) doğru akım güç kaynakları kullanıldı. Reaktörde üretilen flokların boya molekülleri ile homojen çarpışmalarını sağlamak için karıştırıcı olarak Heidolph marka MR Hei-Tec seri dijital manyetik karıştırıcılar kullanıldı.

Şekil 1. Paralel Bağlı Bipolar Reaktör 


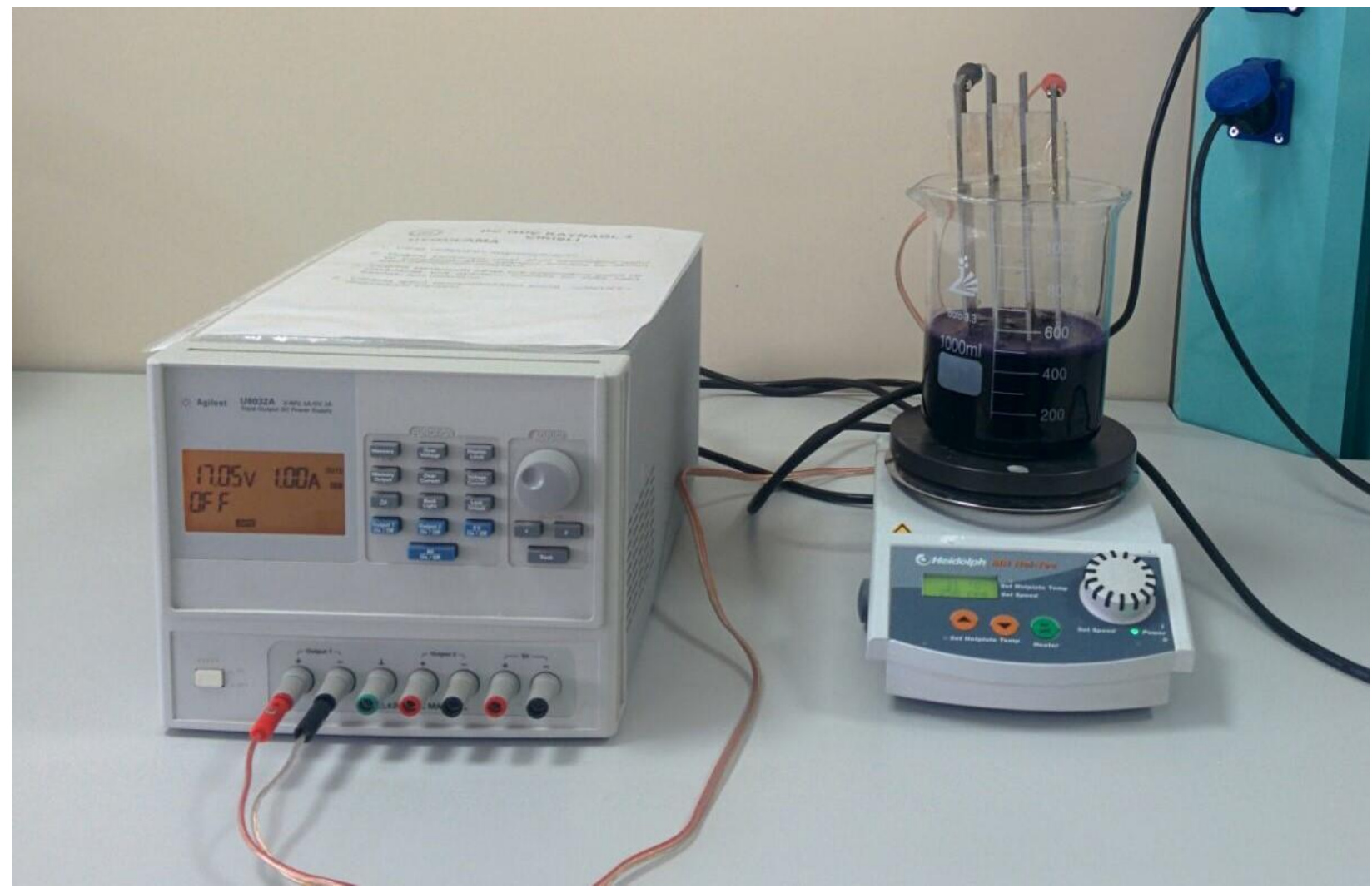

Şekil 2. Deney Düzeneği

\subsection{Deneysel İşlem}

Elektrotlar reaktöre yerleştirildikten sonra hücreye $500 \mathrm{ml}$ boya çözeltisi konuldu. Manyetik karıştırıcıda karıştırma hızı seçildi (rpm) ve güç kaynağı üzerinde istenen akım ve voltaj ayarlaması yapıldıktan sonra çalıştırıldı. Elektrotlar arası gerilimden kaynaklanan sıcaklık artışı, reaktörün dış çeperine dışarıdan hava verilerek $24-26{ }^{\circ} \mathrm{C}$ aralığında tutuldu. Çözelti sıcaklığı lazer termometre kullanılarak takip edildi. Elektrokoagülasyon esnasında oluşan hidrojen gazı yardımıyla floklar reaktörün üst kısmında toplanmış olup, net bir kat1sıvı ayırımı gözlemlendi. Belirlenen süreler sonunda reaktörden alınan numuneler kaba filtre kâğıdından süzüldü. Süzülen numuneler daha sonra UV spektrofotometrede okutuldu. Her deneyden önce elektrotlar, yüzeyinde biriken safsızlıklardan arındırılması amaciyla, önceden hazırlanan temizleme çözeltisinde 3 dakika bekletildi ve safsu ile durulandı. Temizleme çözeltisi \%35 'lik $100 \mathrm{ml}$
$\mathrm{HCl}$ ve \% 2.8 'lik $200 \mathrm{ml}$ hekzametilentetramin $\left(\left(\mathrm{CH}_{2}\right)_{6} \mathrm{~N}_{4}\right)$ çözeltisinden oluşmaktadır [18].

\subsection{Analitik Yöntem}

\subsubsection{Boya Konsantrasyonunun Belirlenmesi}

Çalışmalarda kullanılan farklı konsantrasyonlardaki boya çözeltileri (Reactive Black 39 ve Remazol Red 3B) saf su kullanılarak hazırlandı. WTW marka Photolab 7600 model UV spektrofotometrede, boyanın maksimum absorbans verdiği $\lambda$ max dalga boyunda bir konsantrasyon-absorbans kalibrasyon eğrisi çıkarılmış olup bunlar Şekil 4. (a) ve (b) 'de verildi. Boyanın kendi $\mathrm{pH}$ değeri olan 7 için yapılan bu işlem daha sonra $\mathrm{pH} 4$ ve $\mathrm{pH} 10$ için tekrarlandı ve her bir $\mathrm{pH}$ için maksimum dalga boyunda bir değişiklik olmadığı gözlemlendi ve tüm $\mathrm{pH}$ değerleri için aynı $\lambda \max$ dalga boyu kullanıldı. Deneylerden önce ve sonra yukarıda açıklandığı şekilde UVspektrofotometre ile boya konsantrasyonu ölçüldü. 


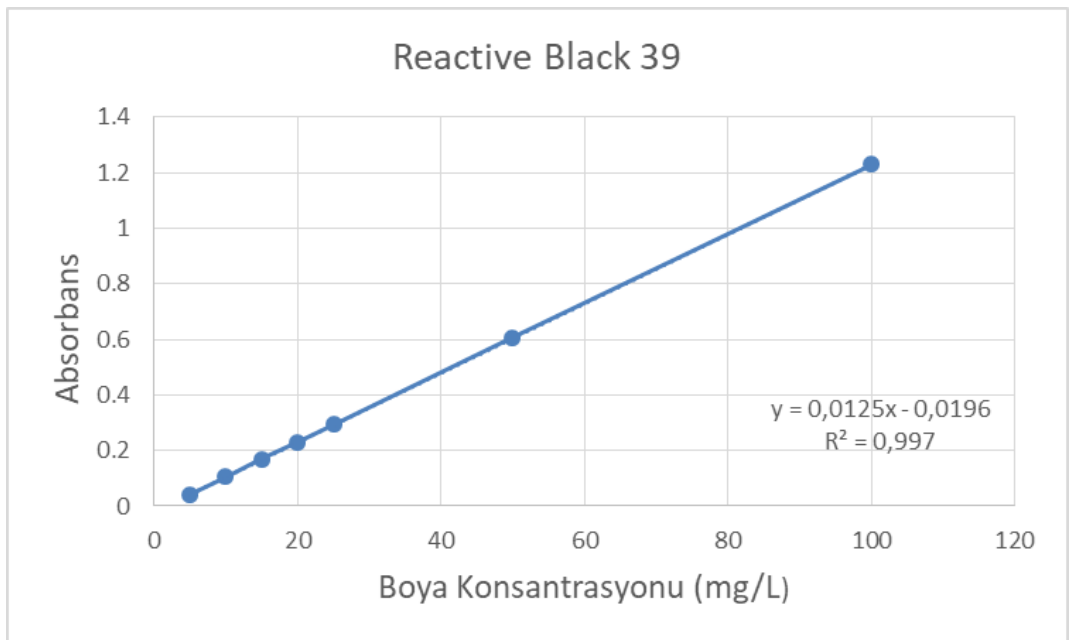

(a)

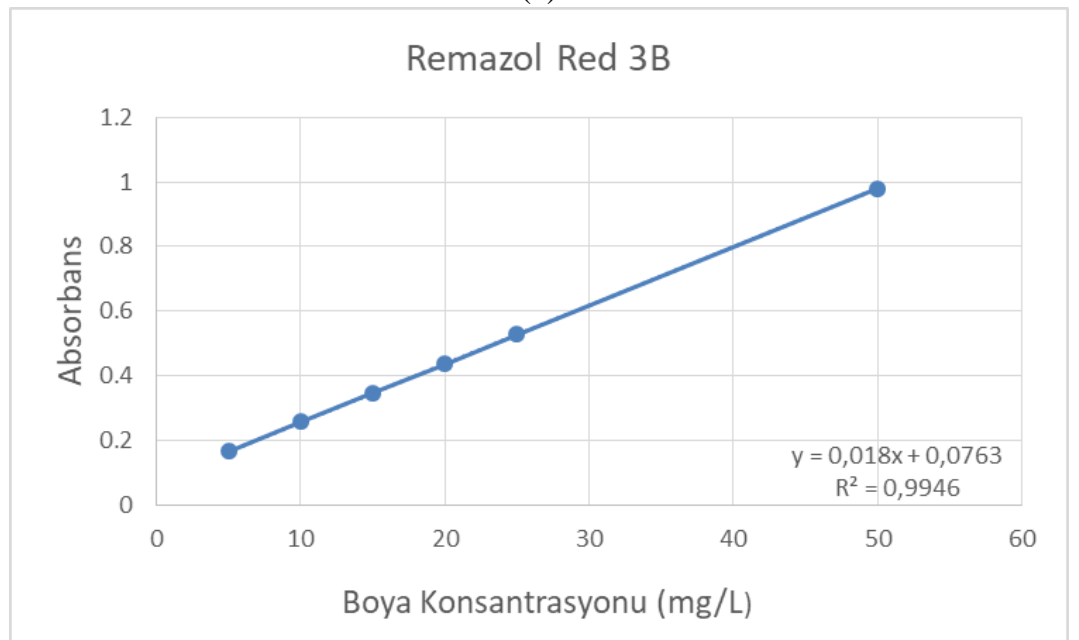

(b)

Şekil 3. Absorbans - Boyarmadde Konsantrasyon Kalibrasyon Eğrisi a) Reactive Balck 39 b) Remazol Red 3B

\subsubsection{Kullanılan Eşitlikler}

Boya (Boyarmadde) giderme verimi, $E$, aşağıdaki eşitlik ile yüzde olarak hesapland.

$E=\frac{C_{i}-C_{f}}{C_{i}} x 100$

Burada; $C_{\text {i }}$ giriş boya konsantrasyonu $(\mathrm{mg} / \mathrm{L})$ ve $C_{\mathrm{f}}$ belirlenen süre sonundaki boya konsantrasyonu (mg/L).

Akım yoğunluğu, J, aşağıdaki eşitlikle hesaplandı.

$J=\frac{I}{A}$

Burada; J: Akım yoğunluğu, mA/ $\mathrm{cm}^{2}, I$ : Akım şiddeti, mili Amper, $A$ : Aktif anot yüzey alanı, $\mathrm{cm}^{2}$ 'dir.

Enerji Tüketimi. Harcanan elektrik enerjisini Watt saat (Wh) cinsinden hesaplarsak,

$E=V * I * t$

Burada; $E$ : Elektrik enerjisi (Wh) , $V$ : volt, $I$ : akım şiddeti (A), $t$. zaman (saat) 'dir.

\section{Bulgular ve Tartışma}

$\mathrm{Bu}$ bölümde farklı molekül ağırlıklarına sahip 2 tekstil boyarmaddesinin farklı $\mathrm{pH}$ değerlerinde gerçekleştirilen giderme verimleri karşılaştırıldı. Deneyler; 1 amper akımda $(10 \mathrm{~mA} / \mathrm{cm} 2$ akım yoğunluğu) ve ortalama $10 \mathrm{~V}$ gerilimde, $250 \mathrm{mg} / \mathrm{L}$ boyarmadde konsantrasyonunda, 100 rpm karıştırma hızında, $15 \mathrm{~mm}$ elektrotlar arası mesafede, 1000 $\mathrm{mg} / \mathrm{L} \mathrm{NaCl}$ elektrolit konsantrasyonunda $\mathrm{pH} 4,5,6$, $7,8,9$ ve 10 için gerçekleştirilmiştir. Elektrokoagülasyon proseslerinde $\mathrm{pH}$ dengesi değişimi anot ve katotta meydana gelen yükseltgenme ve indirgenme reaksiyonları ile kontrol edilmektedir. Anotta, alüminyum yükseltgenirken (çözünürken) katotta ise su indirgenmekte ve $\mathrm{OH}$ iyonları çözeltiye geçerek çözelti $\mathrm{pH}$ sını arttırmaktadır. pH artışı uygulanan akım (Amper) ile doğru orantılıdır. Anotta alüminyum elektrot kullanılması durumunda bu artış alüminyumun amfoterik yapısından dolayı $\mathrm{pH} 9$ dolaylarında dengelenmektedir. Katotta da alüminyum elektrot kullanılması durumunda, 
katodun $\mathrm{OH}$ iyonları saldırısına maruz kalması ve kimyasal çözünmenin meydana geldiği görülmektedir [19]. Bu durum, yani katodik çözünme $\mathrm{pH}$ dengesi üzerinde etkili ve $\mathrm{pH}$ artışını yavaşlatmaktadır. Anılan tüm bu dengeler elektrokoagülasyon esnasında $\mathrm{pH}$ değişimini etkilediğinden, yapılan çalışma boyunca $\mathrm{pH}$ yı istenen değerde tutulmak için çözeltiye gerektiğinde asit veya baz eklendi. Şekil 4, 5, 6 ve 7 'de asidik pH değerleri ( $\mathrm{pH} 4,5,6$, ve 7) için elde edilen renk giderme verimleri görülmektedir. $\mathrm{pH} 4$ alüminyum hidroksit floklarının henüz olgunlaşmadığg ve alüminyumun önemli bir k1smının halen iyon halinde $\left(\mathrm{Al}^{3+}\right)$ bulunduğu $\mathrm{pH}$ dir. $\mathrm{Bu} \mathrm{pH}$ da daha çok monomerik alüminyum hidroksit flokları mevcuttur.
pH arttıkça monomerik alüminyum hidroksit türleri polimerik alüminyum hidroksit türlerine dönüşmektedir. pH 5,5-6 aralı̆̆ 1 ise Alüminyum hidroksit floklarının en iyi çökelme $\mathrm{pH}$ aralığına denk gelmektedir. Bu çalışmada en iyi giderme verimler pH 5 ve 6 için gerçekleşmiştir. pH 7 de ise giderme veriminde nispeten bir düşüş görülmektedir. pH 7 'ye çıkılması ile daha önce pH 4,5 ve 6 da \% 100 giderilen Reactive Black $39 \% \quad 100$ giderilememiştir. Asidik $\mathrm{pH}$ değerleri ( $\mathrm{pH} 4,5,6$, ve 7) için, molekül boyutu daha büyük olan Reactive Black 39 (1021,16 g/mol), molekül boyutu daha küçük olan Remazol Red 3B $(674,10)$ den az bir farkla da olsa çözeltiden daha iyi giderilmiştir.

pH 4

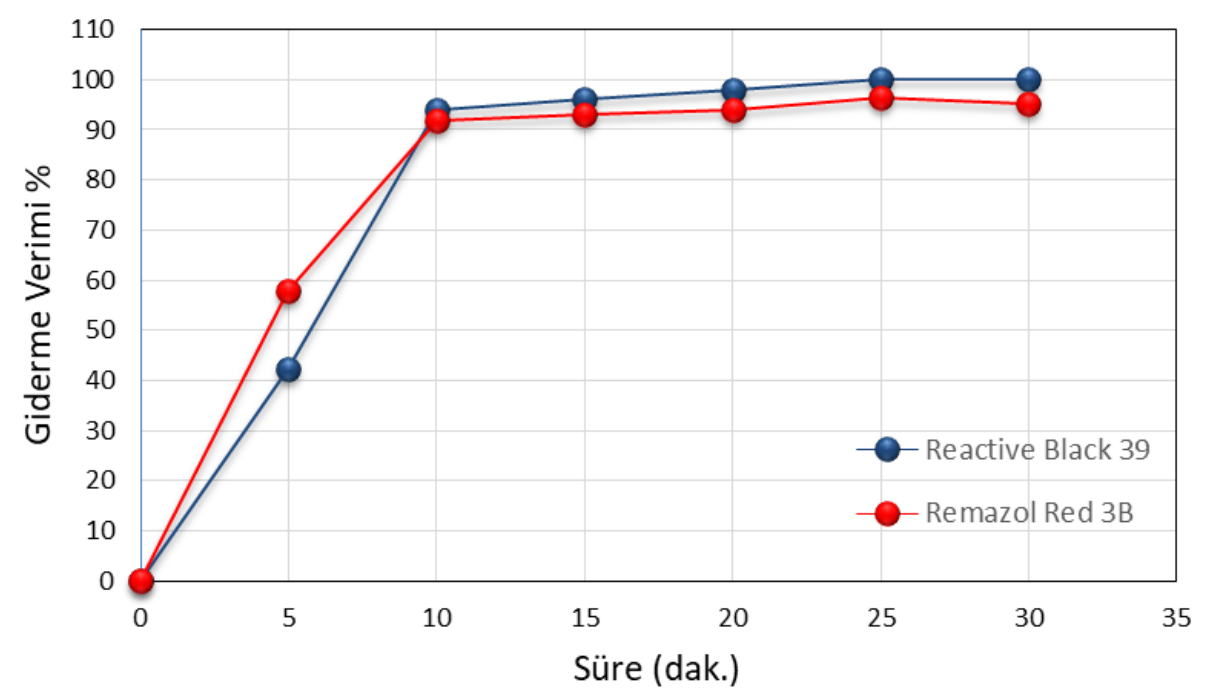

Şekil 4. pH 4 ' Renk Giderme Verimi

pH 5

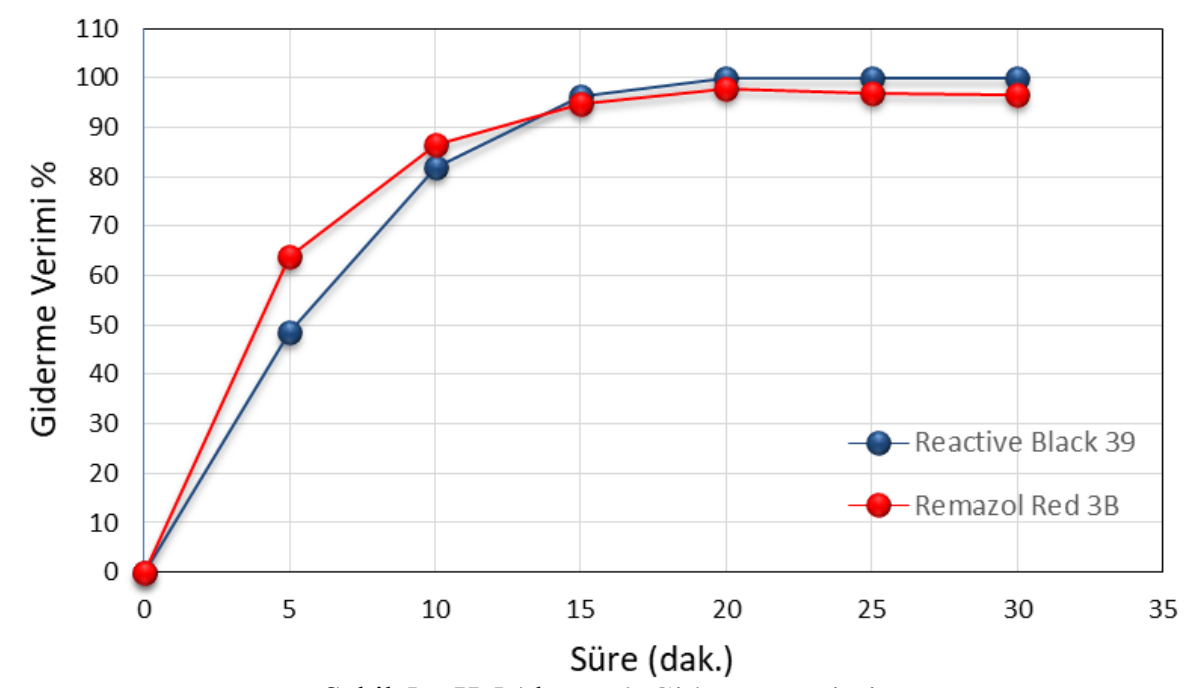

Şekil 5. pH 5 ‘de Renk Giderme Verimi 


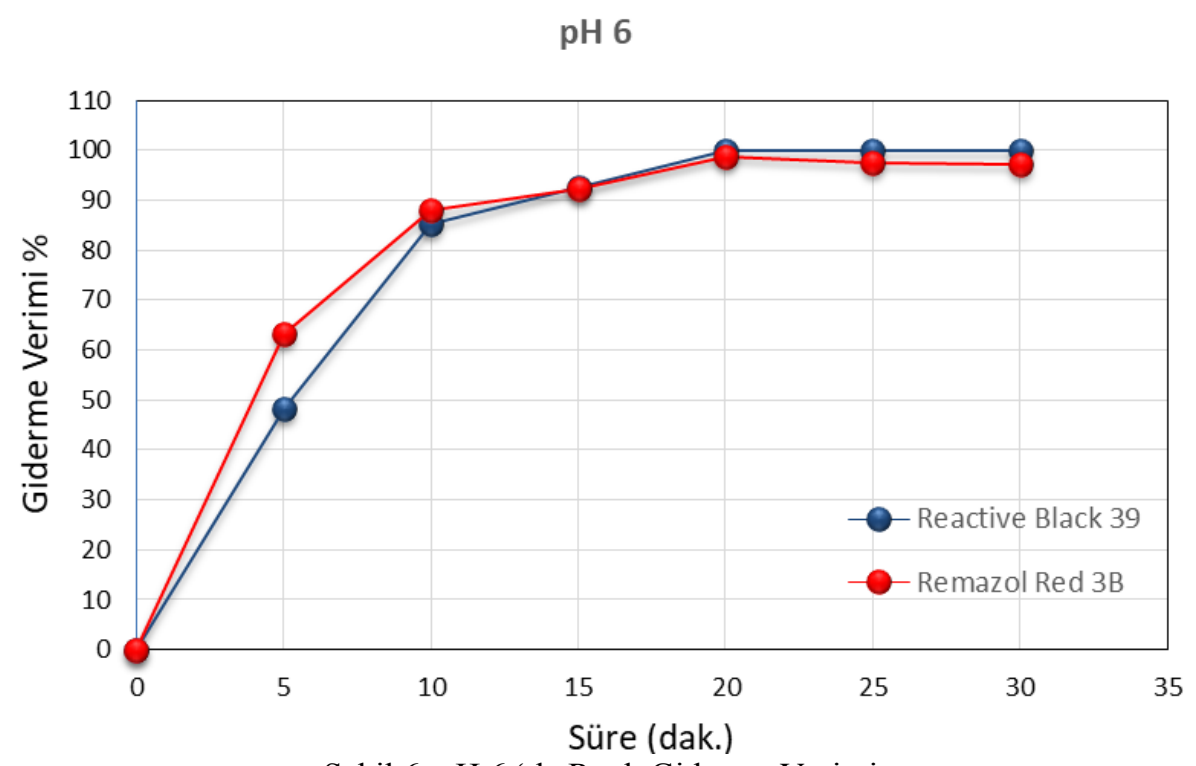

Şekil 6. pH 6 'da Renk Giderme Verimi

pH 7

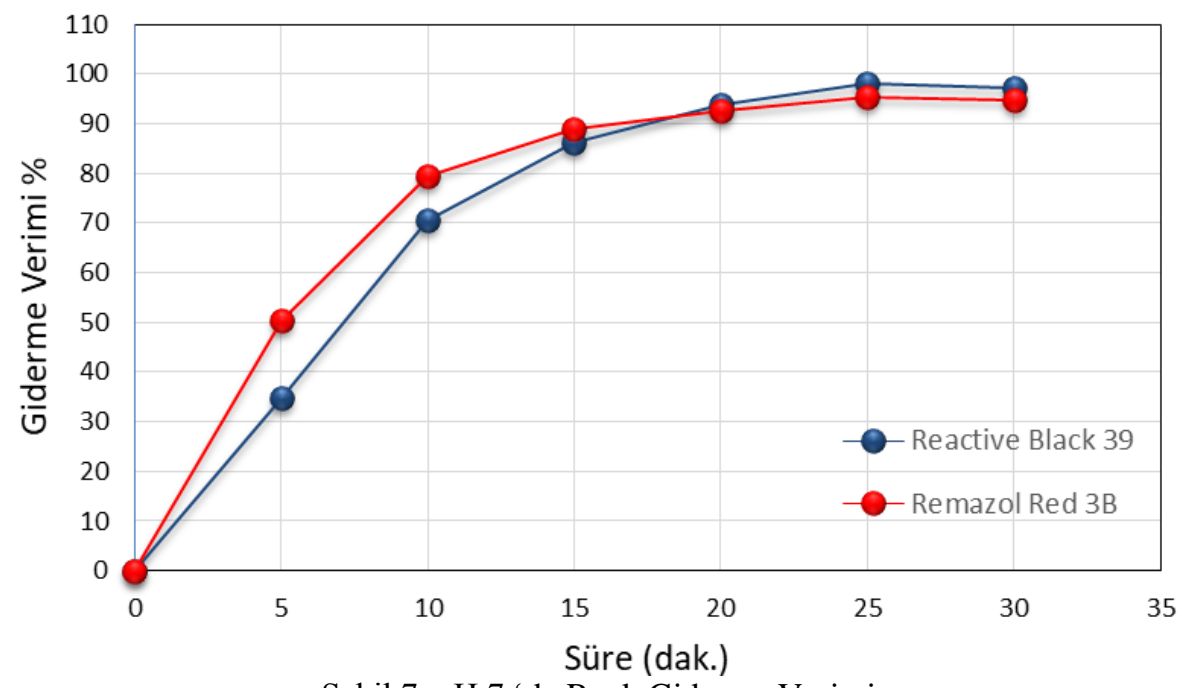

Şekil 7. pH 7 ‘de Renk Giderme Verimi

Şekil 8,9 ve 10 'da bazik $\mathrm{pH}$ değerleri $(\mathrm{pH} 8,9$ ve 10) için elde edilen renk giderme verimleri görülmektedir. Bazik $\mathrm{pH}$ değerlerinde $\mathrm{OH}$ iyonlarının artışı ile birlikte en etkin polimerik alüminyum hidroksit türleri $\left(\mathrm{Al}(\mathrm{OH})_{3}\right)$ yerini $\mathrm{Al}(\mathrm{OH})_{4}{ }^{-}$bileşiğine bırakmakta ve giderme verimi düşmektedir. $\mathrm{Bu} \mathrm{pH}$ değerlerinde her iki boyar madde için giderme verimi kabaca $\mathrm{pH} 8$ de $\% 90, \mathrm{pH}$ 9 ve 10 da \% 80 lere düşmektedir. Bazik pH değerleri (pH 8,9 ve 10) için, asidik $\mathrm{pH}$ değerlerinden farklı olarak, molekül boyutu daha küçük olan Remazol Red 3B $(674,10)$, molekül boyutu daha büyük olan Reactive Black 39 (1021,16 g/mol) den çözeltiden daha iyi giderilmiştir. 
pH 8

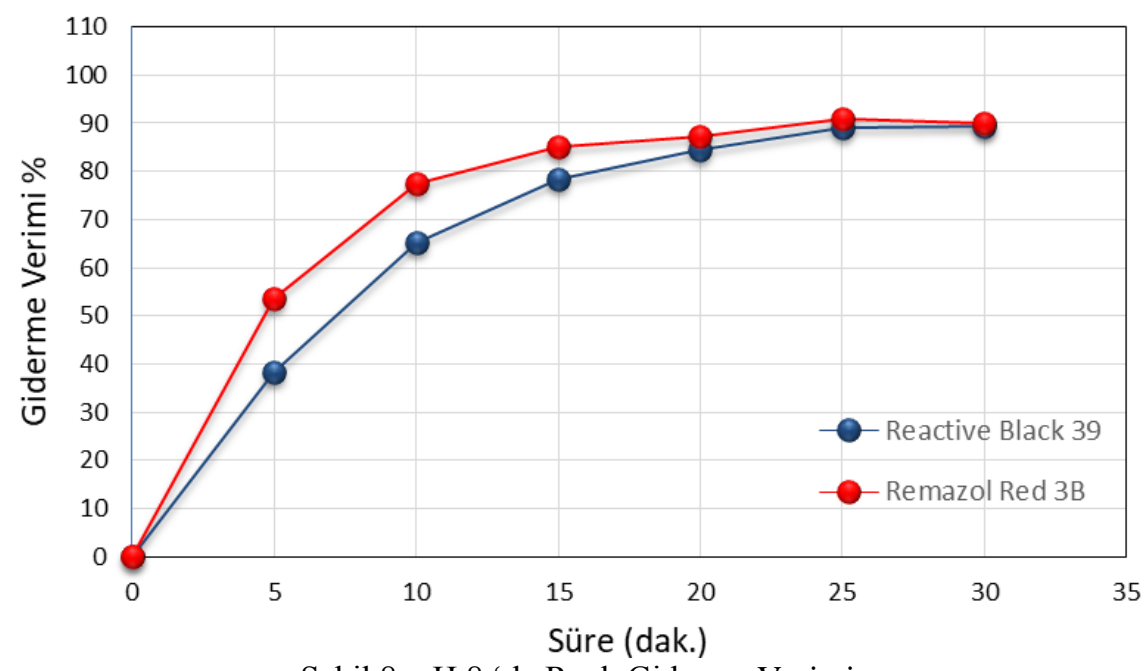

Şekil 8. pH 8 'de Renk Giderme Verimi

pH 9

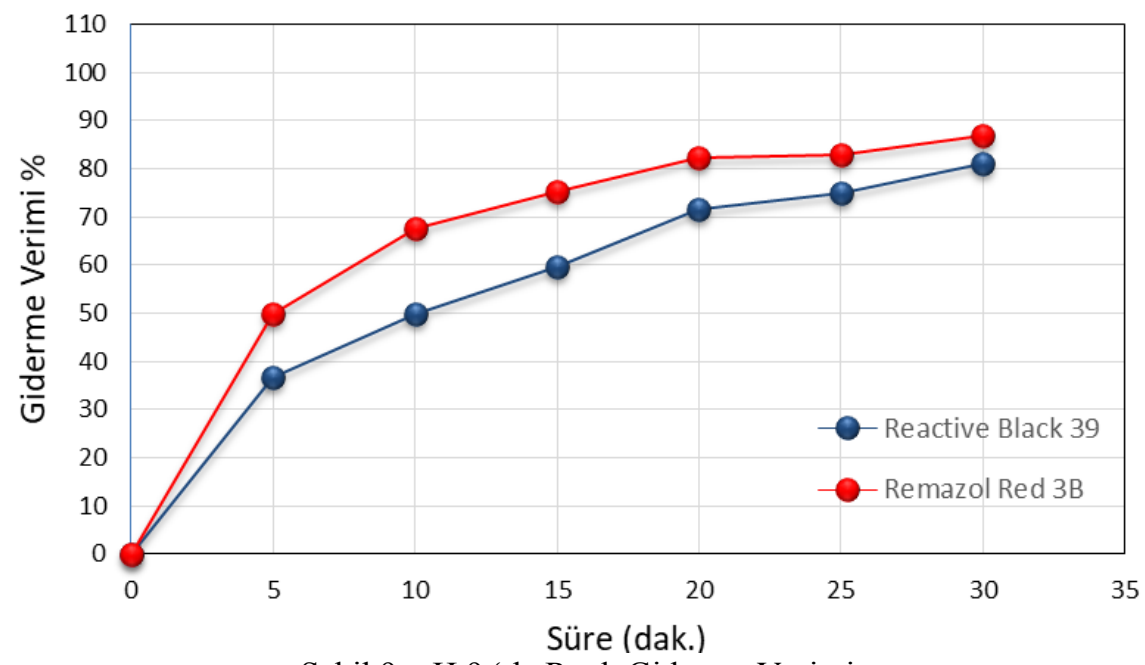

Şekil 9. pH 9 'da Renk Giderme Verimi

pH 10

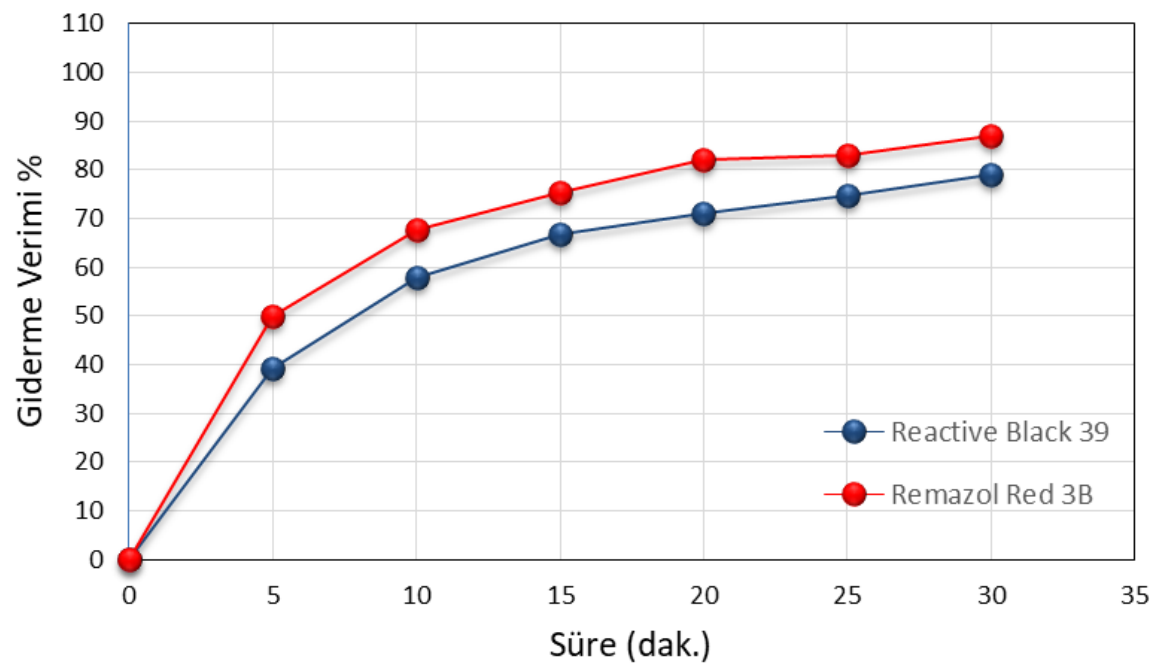

Şekil 10. pH 10 'da Renk Giderme Verimi 
Şekil 11 'de asidik pH 4 ve bazik pH 10 değerleri için elde edilen renk giderme verimleri görülmektedir. Asidik $\mathrm{pH}$ değerinde renk gideriminin bazik $\mathrm{pH}$ değerine göre

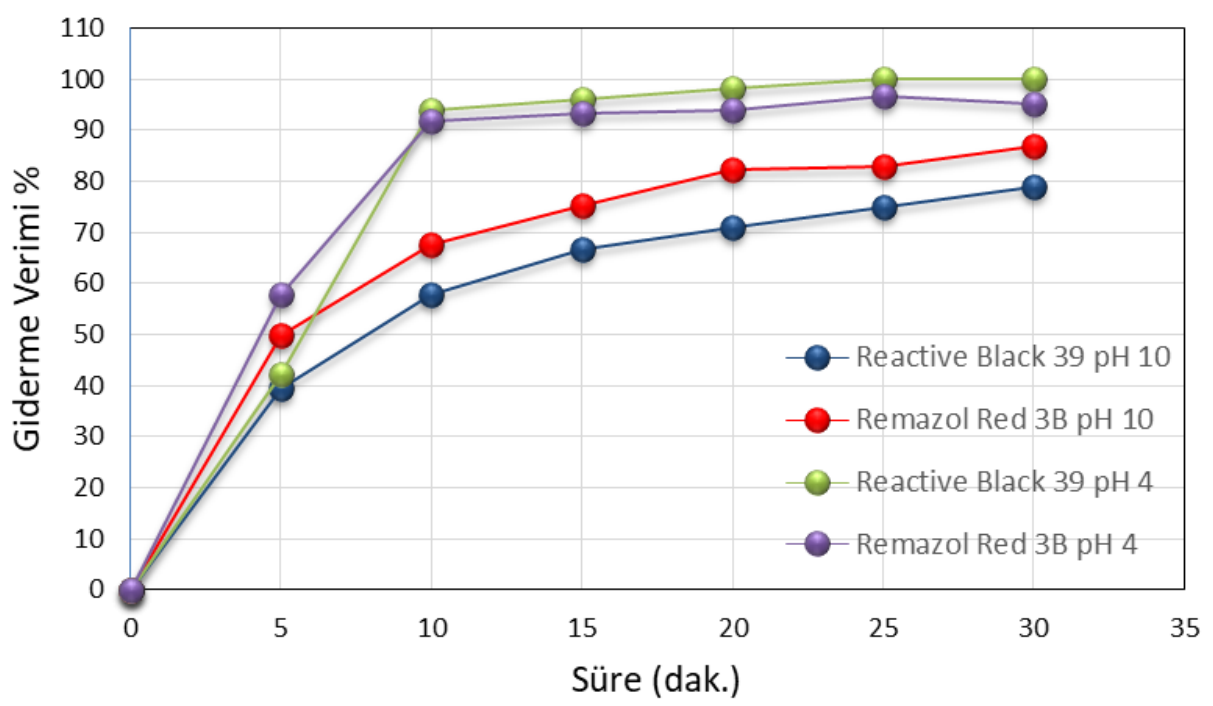

Şekil 11. pH 4 ve pH 10 ‘da Renk Giderme Verimi

Tablo 2. Boyarmadde molekül ağırlığı ve pH ya bağlı giderme verimi değerleri

\begin{tabular}{|c|c|c|c|c|c|c|c|c|c|}
\hline Boyarmadde & Molekül Ağırlı̆ı̆ (g/mol) & Giderime Verimi & $\mathbf{p H ~ 4}$ & $\mathbf{p H ~ 5}$ & $\mathbf{p H ~ 6}$ & $\mathbf{p H ~ 7}$ & $\mathbf{p H ~ 8}$ & $\mathbf{p H ~ 9}$ & $\mathbf{p H ~ 1 0}$ \\
\hline Reactive Black 39 & 1021.16 & \multirow{2}{*}{$*$} & 100 & 100 & 100 & 98 & 89.21 & 74.8 & 74.83 \\
\hline Remazol Red 3B & 674.10 & & 96.54 & 96.94 & 97.35 & 95.49 & 90.97 & 83.01 & 83.01 \\
\hline
\end{tabular}

25. dakika giderme verimleri

pH artışından daha büyük molekül ağırlığına sahip olan boyar madde daha çok etkilenmektedir. Tablo 2 'de görüleceği üzere, boyarmadde gidermede daha büyük molekül ağırlığına sahip olan Reactive Black 39 (1021.16 g/mol) pH değişiminden \% 100 'den 74.83 'e düşüşle, yaklaşık \% 25 oranında etkilenirken, daha küçük molekül ağırlığına sahip olan Remazol Red 3B (674.10 g/mol) \% 96.54 'den 83.01 'e düşüşle yaklaşık \% 13 oranında etkilenmektedir. Sudaki kolloidal kirleticilerin alüminyum hidroksit flokları tarafından, flok içerisine hapsetme veya flok yüzeyinde tutunma şeklinde giderildikleri bilinmektedir. $\mathrm{pH}$, elektrokimyasal ve kimyasal koagülasyon süreçlerinde önemli bir faktördür; elektrokimyasal olarak çözünmüş Al'ın hidrolizi ve polimerizasyon reaksiyonları yoluyla çeşitli kompleksler ve polimerik bileşikler oluşmaktadır. [20] pH'nın elektrokoagülasyon prosesine etkisi, başlangıçta oluşan alüminyum hidroksitin çözünürlüğü ile ilgilidir. $\mathrm{pH}<5.4$ olduğunda, $\mathrm{Al}(\mathrm{OH})_{3}$ hidrolize olur ve $\mathrm{Al}^{3+}, \mathrm{Al}(\mathrm{OH})^{2+}, \mathrm{Al}(\mathrm{OH})_{2}{ }^{+}$gibi monomerik türler ortaya çıkar; [20] ve negatif zeta potansiyeline sahip partikülleri üzerlerine adsorbe edebilirler. [21] Öte yandan, pH'da bir azalma, iyonik kuvvetin artmasına yol açar; bu, $\mathrm{Al}(\mathrm{OH})_{3}$ partikülleri arasındaki elektriksel çekimin azalması ve pıhtılaşması yanı sıra etkileşimlerini (adsorpsiyon kapasitesi) azaltır. 6 ila 9 arasında değişen pH'da alüminyum hidroksit çökeltmesi ortaya çıkar; Alüminyum hidroksit parçacıklarının yüzeyi üzerinde oluşabilecek kristaller veya bulk içinde oluşan hidroksit çökeltileri kendilerini diğer parçacıklara tutturabilir. 9'dan daha yüksek $\mathrm{pH}$ değerlerinde, boya gibi parçacıkları sabitlemede düşük afiniteye ve adsorbsiyona sahip alüminat iyonları $\mathrm{Al}(\mathrm{OH})_{4}^{-}$ baskın hale gelir.[15] Yüksek pH değerlerinde flok üretimi ve çökelmesi azaldığından molekül kütlesi büyük olan boyanın giderimi azalmaktadır. Giderme verimindeki bu düşüşün nedeni büyük moleküllün azalan flok içerisine nüfuzunun veya flok yüzeyinde tutunmasının küçük moleküle göre zorluğu olarak düşünülmektedir.

\section{Sonuç ve Öneriler}

Alüminyum elektrotların kullanıldığ paralel bağlı bipolar reaktöre sahip elektrokoagülasyon yöntemi ile boyarmaddelerin su ortamından giderimi başarı ile sağlandı. Asidik pH değerlerinde \% 100 e yakın giderme değerleri elde edilirken, bazik $\mathrm{pH}$ değerlerinde giderme verimlerinin düştüğü görüldü. Hem boyarmadde molekül ağırlığı büyük olan Reactive Black 39 hem de molekül ağırlığı küçük olan Remazol Red 3B düşük pH değerinde sudan daha iyi giderilmektedir. Yüksek $\mathrm{pH}$ değerlerinde ise her iki boyarmaddenin de sudan giderimi azalmaktadır. Alüminyum elektrot kullanılan 
elektrokoagülasyon proseslerinde oluşan alüminyum hidroksit flokları için optimum çökelme pH sı olan 5.5-6 aralığında en iyi giderme verimi boyarmadde molekül ağırlığı büyük olan Reactive Black 39 için gerçekleşti. Bu sonuçlardan elektrokoagülasyon ile sulardan boyarmadde gideriminde hem boyarmadde molekül büyüklüğünün hem de $\mathrm{pH}$ nın önemli bir ortak etkisinin olduğu görüldü.

\section{Kaynaklar}

[1] M. Sleiman, D. Vildozo, C. Ferronato, and J.-M. Chovelon, "Photocatalytic degradation of azo dye Metanil Yellow: Optimization and kinetic modeling using a chemometric approach," Appl. Catal. B Environ., vol. 77, no. 1, pp. 1-11, 2007.

[2] V. Shah and D. Madamwar, "Community genomics: Isolation, characterization and expression of gene coding for azoreductase," Int. Biodeterior. Biodegradation, vol. 79, pp. 1-8, 2013.

[3] C. Ahmed Basha, N. S. Bhadrinarayana, N. Anantharaman, and K. M. Meera Sheriffa Begum, "Heavy metal removal from copper smelting effluent using electrochemical cylindrical flow reactor," $J$. Hazard. Mater., vol. 152, no. 1, pp. 71-78, 2008.

[4] O. T. Can, M. Kobya, E. Demirbas, and M. Bayramoglu, "Treatment of the textile wastewater by combined electrocoagulation," Chemosphere, vol. 62, no. 2, 2006.

[5] N. Mohan, N. Balasubramanian, and C. A. Basha, "Electrochemical oxidation of textile wastewater and its reuse," J. Hazard. Mater., vol. 147, no. 1, pp. 644-651, 2007.

[6] M. M. and L. L. P.Balaji, B.Vignesh, M.Sowmiya, "Removal of Colour from Textile Effluent using Natural Adsorbent (Calotropis Gingantea)," Int. J. Innov. Eng. Technol., vol. 5, no. 4, p. 265, 2015.

[7] S. Aoudj, A. Khelifa, N. Drouiche, M. Hecini, and H. Hamitouche, "Electrocoagulation process applied to wastewater containing dyes from textile industry," Chem. Eng. Process. Process Intensif., vol. 49, no. 11, pp. 1176-1182, 2010.

[8] M. Bayramoglu, M. Kobya, O. T. Can, and M. Sozbir, "Operating cost analysis of electroagulation of textile dye wastewater," Sep. Purif. Technol., vol. 37, no. 2, 2004.

[9] O. T. Can, M. Bayramoglu, and M. Kobya, "Decolorization of reactive dye solutions by electrocoagulation using aluminum electrodes," Ind. Eng. Chem. Res., vol. 42, no. 14, 2003.

[10] M. Kobya, E. Demirbas, O. T. Can, and M. Bayramoglu, "Treatment of levafix orange textile dye solution by electrocoagulation," J. Hazard. Mater., vol. 132, no. 2-3, 2006.

[11] T. K. Dawood, Sara. Sen, "Review on Dye Removal from Its Aqueous Solution into Alternative Cost Effective and Non-Conventional Adsorbents," J Chem Proc Engg, vol. 1, no. 1, pp. 1-11, 2014.
[12] E. Pajootan, M. Arami, and N. M. Mahmoodi, "Binary system dye removal by electrocoagulation from synthetic and real colored wastewaters," J. Taiwan Inst. Chem. Eng., vol. 43, no. 2, pp. 282-290, 2012.

[13] N. Ardhan, T. Ruttithiwapanich, W. Songkasiri, and C. Phalakornkule, "Comparison of performance of continuous-flow and batch electrocoagulators: A case study for eliminating reactive blue 21 using iron electrodes," Sep. Purif. Technol., vol. 146, no. Supplement C, pp. 75-84, 2015.

[14] B. K. Nandi and S. Patel, "Effects of operational parameters on the removal of brilliant green dye from aqueous solutions by electrocoagulation," Arab. J. Chem., vol. 10, no. Supplement 2, pp. S2961-S2968, 2017.

[15] M. K. Mbacké et al., "Electrocoagulation process applied on pollutants treatmentexperimental optimization and fundamental investigation of the crystal violet dye removal," $J$. Environ. Chem. Eng., vol. 4, no. 4, Part A, pp. 40014011, 2016.

[16] S. Zodi, B. Merzouk, O. Potier, F. Lapicque, and J.-P. Leclerc, "Direct red 81 dye removal by a continuous flow electrocoagulation/flotation reactor," Sep. Purif. Technol., vol. 108, no. Supplement C, pp. 215-222, 2013.

[17] A. R. Amani-Ghadim, S. Aber, A. Olad, and H. Ashassi-Sorkhabi, "Optimization of electrocoagulation process for removal of an azo dye using response surface methodology and investigation on the occurrence of destructive side reactions," Chem. Eng. Process. Process Intensif., vol. 64, no. Supplement C, pp. 68-78, 2013.

[18] A. Akyol, O. T. Can, and M. Bayramoglu, "Treatment of hydroquinone by photochemical oxidation and electrocoagulation combined process," J. Water Process Eng., vol. 8, 2015.

[19] T. Picard, G. Cathalifaud-Feuillade, M. Mazet, and C. Vandensteendam, "Cathodic dissolution in the electrocoagulation process using aluminium electrodes," J. Environ. Monit., vol. 2, no. 1, pp. 77-80, 2000.

[20] J. Prakash Kushwaha, V. Chandra Srivastava, and I. Deo Mall, "Studies on electrochemical treatment of dairy wastewater using aluminum electrode," AIChE J., vol. 57, no. 9, pp. 2589-2598, 2011.

[21] A. Gürses, M. Yalçin, and C. Doğar, "Electrocoagulation of some reactive dyes: a statistical investigation of some electrochemical variables," Waste Manag., vol. 22, no. 5, pp. 491499, 2002. 